\title{
Regional Determinants of Foreign Direct Investment in Manufacturing Industry
}

\author{
Kelly Liu ${ }^{1}$, Kevin Daly ${ }^{1} \&$ Maria Estela Varua ${ }^{1}$ \\ ${ }^{1}$ School of Business, University of Western Sydney, Sydney, Australia \\ Correspondence: Kevin Daly, School of Business, University of Western Sydney, Sydney, Australia. E-mail: \\ K.Daly@uws.edu.au
}

Received: October 2, 2012

Accepted: October 30, 2012

Online Published: November 5, 2012

doi:10.5539/ijef.v4n12p178

URL: http://dx.doi.org/10.5539/ijef.v4n12p178

\begin{abstract}
Since China opened its economy to foreign investment in 1979, it has become the second largest Foreign Direct Investment (FDI) destination in the world after the USA. Over the past three decades, the manufacturing sector has dominated China's FDI inflow, however, when manufacturing activity is bifurcated into low and high technology classes, it becomes evident that China is in a transition stage, moving from FDI in traditional low-tech manufacturing activity to a high-tech manufacturing environment. This paper attempts to analyse the key determinants of FDI inflow across low and high technology manufacturing industry across the four geographical regions of China. In the paper we empirically investigate the determinants of FDI inflows to both high and low-tech manufacturing industries by market size, labor cost, labor quality, and government spending on human capita.
\end{abstract}

Keywords: China, FDI, manufacturing industry, low high technology

\section{Introduction}

Since China reformed and adopted the 'open up' policy in 1979, foreign direct investment (FDI) has increased substantially from almost no foreign investment to USD105.74 billion in 2010. FDI is widely recognised as one of the major drivers behind economic growth in China; responsible for increasing productivity, efficiency, technology and improvement in management know-how through spill-over effects (Whally \& Xin, 2010; Wei and Liu, 2006; Liu, 2008; Yao, 2006). However the uneven distribution of FDI across the regions has contributed to the regional economic disparity between coastal and non-coastal regions, namely the northeast, central and western regions (Chen, Ge \& Lai, 2011). To appreciate the disparity in economic growth across the regions it is first necessary to identify the factors that contribute to the inflow of FDI in each region.

Initially this paper focuses on identifying the regional determinants of FDI inflows in both high-technology and low-technology categories of the manufacturing industry. The distinction between these two types of technology is necessary at the outset so that we can plot the distribution of these technologies across China's regions. Overall our data confirms that foreign investors invest proportionately more in manufacturing activity as opposed to' primary or tertiary sectors. Furthermore our analysis reveals that the manufacturing industry received more than 60 per cent of total utilized FDI inflow. Initially, the largest FDI investments go to the manufacturing industry due in part to the large supply of skilled and unskilled labor and the relatively lower cost of materials compared to the other sectors, however, with adopted foreign capital, management know-how, trained labour and technology spill-over effect, China also possesses the capacity to adopt high-technology intensive manufacturing activities, such as manufacturing of communication equipment, transport equipment and machinery and electronic equipments.

China is still in the process of industrialization, and FDI in manufacturing plays an important role in the national economy as it has a huge effect on industrial upgrading, technical advancement, and export competitiveness (Yang, 2010). In the past few decades China's manufacturing industry has made outstanding progress and has became the world's largest producer of more than 100 products, including textiles, apparel, sheet glasses, fertilizer, refrigerators and television. However after Global Financial Crisis (GFC) of 2008 the demand for low-tech products decreased while the international demand for high-tech products has increased as the latter is found to have positive effects on productivity and competitiveness when used throughout economy (OECD, 
2009). At present, it seems beneficial for China to attract FDI in high-tech manufacturing industry rather than traditional low-tech manufacturing industries.

Furthermore FDI provides host countries like China access to new technology, capital, research \& development facilities and management know-how as China become a favoured host location for manufacturing activities which in turn contributes positively to China's economic development. Some scholars however argue that the uneven distribution of FDI is responsible for widening a host of regional economic disparities which in turn leads to an uneven development map of China (Wei, Yao \& Liu, 2009). Our analysis suggests that FDI can also be a major contributor to increasing economic growth across the underdeveloped non-coastal regions but this can only be realised under careful planning at the regional level with the correct mix of technologies driving this development. Sun and Chai (1998) and Lin et al (2011) argue that the spillover effects of FDI depend heavily on host region's absorptive ability. The inequality between coastal and non-coastal regions may imply that the degree of technological capability varies substantially across regions as each region promotes its own comparative advantages, i.e. the coastal region with traditionally employs highly trained labour and has a record of industrial development focused on attracting FDI in high-technology manufacturing industries. However the western and central regions are rich in natural resource and would benefit from employing workers in appropriate low-technology manufacturing rather than attracting technology-intensive FDI.

This paper examines specific determinants of both the high- and low-technology manufacturing industries across the four regions of China in particular we estimate the significance of size (regional economy), labour costs, labour quality, physical and technology infrastructure as determinants for locating high/ low technologies in manufacturing activities across all of China's four regions. The structure of this chapter is as follow: section 2 describes the transformation and regional distribution of FDI in manufacturing industry among four regions. Section 3 reviews the previous studies on location determinants of FDI and section 4 presents determinant variables of FDI inflows in both high-tech and low-tech categories. Data and analytical framework and empirical results will be present in section 5 and 6 , respectively. The conclusion and policy implications are presented in section 7.

\section{Regional Distribution of FDI Inflows to both High and Low-technology Manufacturing Industries}

The OECD classifies all manufacturing industries (Note 1) into 4 categories based on technology intensity namely: high technology category, medium-high technology category, medium-low technology category and low technology category. Technology intensity is measured by two indicators: R\&D expenditure divided by value added of products and R\&D expenditure divided by production cost. Industries ranked in higher technology category have higher research intensity indicators compared to industries in lower category. For simplicity, this paper classifies manufacturing industries in China into only two categories, namely: low-technology (low and medium-low technology) and high-technology (medium-high and high technology) categories. Table 1 indicates that the high-technology manufacturing category includes the following: pharmaceutical, medicinal chemicals and botanical products, telecommunication, office machinery, chemical and chemical products, machinery and equipments, electrical machinery and transport equipment. The low-technology manufacturing industries include food and beverages production, tobacco production, textiles, wearing apparel, paper and paper products, coke and petroleum production, non-metallic mineral production, basic metal production and fabricated metal production.

Figure 1 shows the amount of utilised FDI inflows in both high and low-tech manufacturing industries for 2001, 2005 and 2008, respectively where FDI increased dramatically especially for the high-tech category. The rate of growth of total FDI in low-tech activities grew from USD 30.3 billion in 2001 to USD 106.1 billion in 2008, an increase of 250 per cent while the high-tech category grew from USD40.2 billion to USD 208.3 billion equivalent to an increase around 418 per cent. Although China has a strong comparative advantage in low-tech, labour-intensive activities not only due to its abundant supply of labour, its comparative advantage in high-tech activities has been driven by high economic growth, huge improvement in human capital development and technology spill-over from previous FDI (Shaukat \& Guo, 2005; Chen, 2011). As a result, the distribution of FDI among high and low-tech categories has changed. As shown in table 2 columns 2 and 4 , the share of utilised FDI in high-tech category reached 66.3 per cent of total national utilised manufacturing FDI in 2008, an increase of 9.2 per cent compared to that in 2001, while the share of FDI in low-tech category has continued to fall, it decreased from 42.9 per cent in 2001 to 32.7 per cent in 2008. 
Table 1. Classifications of manufacturing industries by high and low technology category *

\begin{tabular}{l|l}
\hline \multirow{4}{*}{ High-technology category } & Manufacture of pharmaceuticals, medicinal chemicals and botanical products \\
\cline { 2 - 2 } & Manufacture of radio, television and communication equipment and apparatus \\
\cline { 2 - 2 } & Manufacture of office, accounting and computing machinery \\
\cline { 2 - 2 } & Manufacture of chemicals, chemical products and fibres \\
\cline { 2 - 2 } & Manufacture of machinery and equipment n.e.c. \\
\cline { 2 - 2 } & Manufacture of electrical machinery and apparatus n.e.c. \\
\cline { 2 - 2 } & Manufacture of transport equipment \\
\hline \multirow{5}{*}{ Low-technology category } & Manufacture of food products and beverages \\
\cline { 2 - 2 } & Manufacture of tobacco products \\
\cline { 2 - 2 } & Manufacture of textiles \\
\cline { 2 - 2 } & Manufacture of wearing apparel; dressing and footwear \\
\cline { 2 - 2 } & Manufacture of paper and paper products \\
\cline { 2 - 2 } & Manufacture of coke, refined petroleum products and nuclear fuel \\
\cline { 2 - 3 } & Manufacture of other non-metallic mineral products \\
\cline { 2 - 2 } & Manufacture of basic metals \\
\cline { 2 - 3 } & Manufacture of fabricated metal products, except machinery and equipment \\
\hline
\end{tabular}

Source: OECD and National Bureau of Statistics of China, Note :n.e.c. indicates not elsewhere classified

Note: * With continuing open up, in order to increase international comparison and information communication, China adopted the 'Industrial Classification for National Economic Activities (GB/T475-2011) in 2011. This classification mainly obeys the same principle, methods and industrial classification system as ISIC Rev.3, but with adjustment of some classes' context compare to ISIC. For instance, the manufacturing industry has 30 divisions in GB/T44754-2011, but in ISIC Rev.3, it has 23 divisions. Nevertheless, the author set up corresponding classes and transits the Chinese manufacturing industry classification into ISIC Rev.3 and classify them into different technology categories.

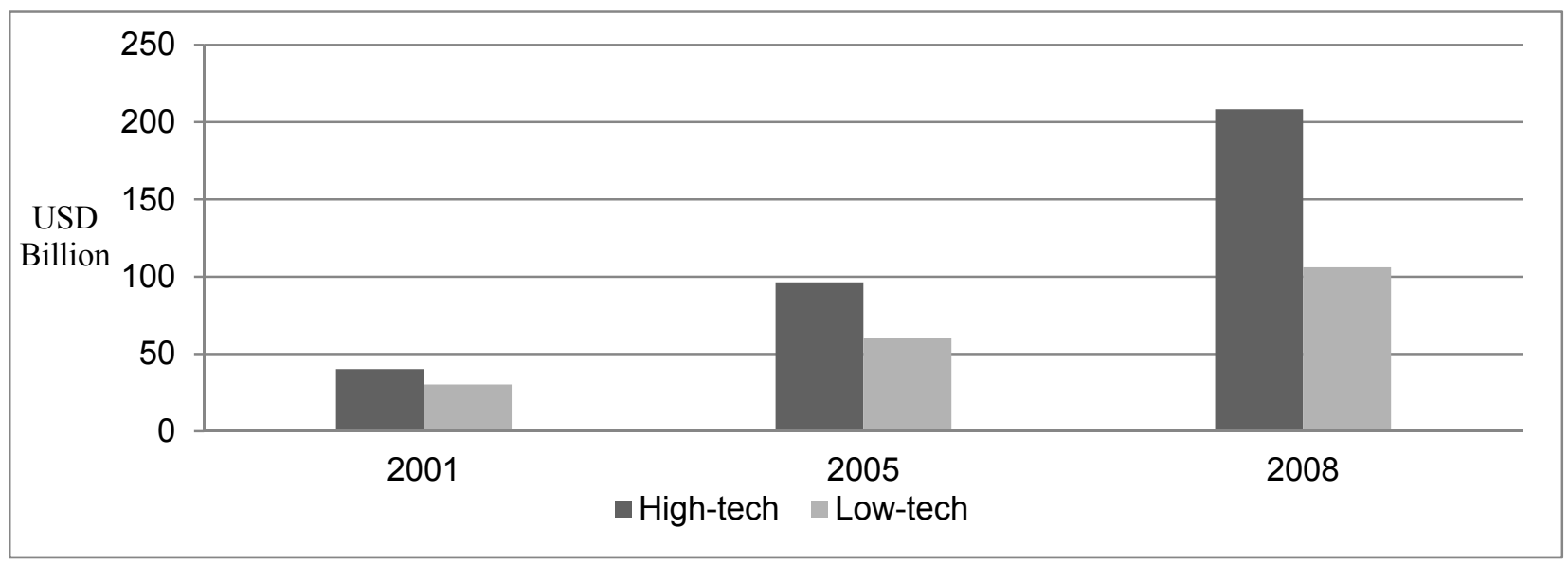

Figure 1. Utilized FDI inflow in both High and Low-tech Manufacturing Industry in China, 2001, 2005 \& 2008 (USD billion)

Source: China Industrial Economic Statistical Yearbook and authors' own calculation

Table 2 reveals that the expansion of FDI across high-tech manufacturing industries over 2001- 2008 was concentrated in radio, television and communication equipment industry (493 per cent), as well as the machinery equipment(480 per cent) and transport equipment industries (414 per cent), (Column 5 , table 2 ). In 2008, the radio, television and communication equipment industries attracted the largest amount of FDI totalling USD 72.2 billion, which accounting for 23 per cent of the total utilised FDI in the manufacturing industry, followed by chemicals and the chemical product industry (USD 33.9 billion \& 10.8 per cent), machinery and equipment industry (USD 33.1 billion \& 10.5 per cent), and transport equipment industry (USD 29.5 billion \& 9.4 per cent). Among all low-tech manufacturing industries, the manufacturing of basic metal has increased the most, compared to 2001 increasing from USD 2.6 billion to USD 15.9 billion an increase of 517 per cent. The paper 
and paper product industry recorded an increase of 290 per cent increase, textile industry at 270 per cent while the coke, refined petroleum products and nuclear fuel industry experienced an increase of 214 per cent. The tobacco industry is the only industry that experienced a fall in FDI, a decrease of 57 per cent from 2001 to 2009 , although the dollar amount is less than USD 0.1 billion

Table 2. Amount and shares of utilised FDI in manufacturing by industries (USD billion \& \%)

\begin{tabular}{|c|c|c|c|c|c|}
\hline & \multicolumn{2}{|c|}{2001} & \multicolumn{2}{|c|}{2008} & \multirow{3}{*}{$\begin{array}{c}\text { Change in } \\
\text { dollar } \\
\text { amount }\end{array}$} \\
\hline & USD & & USD & & \\
\hline & billion & $\%$ & billion & $\%$ & \\
\hline & $(1)$ & (2) & (3) & (4) & (5) \\
\hline \multicolumn{6}{|l|}{ High-technology category } \\
\hline Pharmaceuticals, medicinal chemicals and botanical products & 1.7 & 2.5 & 7.2 & 2.3 & 315.9 \\
\hline Radio, television and communication equipment and apparatus & 12.2 & 17.3 & 72.2 & 23.0 & 493.1 \\
\hline Office, accounting and computing machinery & 1.4 & 2.0 & 6.4 & 2.0 & 351.3 \\
\hline Chemicals, chemical products and fibers & 7.2 & 10.2 & 33.9 & 10.8 & 371.7 \\
\hline Machinery and equipment n.e.c. & 5.7 & 8.1 & 33.1 & 10.5 & 479.7 \\
\hline Electrical machinery and apparatus n.e.c. & 6.3 & 8.9 & 26.0 & 8.3 & 314.5 \\
\hline Transport equipment & 5.7 & 8.2 & 29.5 & 9.4 & 413.9 \\
\hline Sub-Total & 40.2 & 57.1 & 208.3 & 66.3 & 417.7 \\
\hline \multicolumn{6}{|l|}{ Low-technology category } \\
\hline Food products and beverages & 9.3 & 13.2 & 16.7 & 5.3 & 80.1 \\
\hline Tobacco products & 0.0 & 0.1 & 0.0 & 0.0 & -56.7 \\
\hline Textiles & 5.1 & 7.3 & 19.1 & 6.1 & 273.5 \\
\hline Wearing apparel; dressing and footwear & - & & 10.2 & 3.2 & - \\
\hline Paper and paper products & 3.1 & 4.5 & 12.3 & 3.9 & 290.1 \\
\hline Coke, refined petroleum products and nuclear fuel & 0.9 & 1.3 & 3.3 & 1.1 & 269.7 \\
\hline Non-metallic mineral products & 5.0 & 7.2 & 15.9 & 5.0 & 214.4 \\
\hline Basic metals & 2.6 & 3.6 & 15.9 & 5.0 & 517.3 \\
\hline Fabricated metal products, except machinery and equipment & 4.2 & 5.9 & 12.6 & 4.0 & 203.8 \\
\hline Sub-Total & 30.3 & 42.9 & 106.1 & 33.7 & 250.2 \\
\hline
\end{tabular}

Source: China industrial statistical yearbook and authors own calculation

FDI inflows across both high-tech and low-tech manufacturing industries exhibits a strong location preference, both activities appear to be highly concentrated in the coastal region, with very little flowing toward the northeast, central and western regions. Figures (2A) and (2B) show clear signs of uneven regional distributed of utilised FDI in both high and low-technology manufacturing categories over the period 2001-2008. For high-tech category, coastal region had a share of 88 percent of total FDI, while the northeast, central and western regions only received 5, 4 and 3 percent, respectively. The location preference is a result of a variety of factors, including FDI policies and the stage of regional economic development. The coastal region received privileged status which in turn brought forward comparative advantages in infrastructure, capital, technology and management skills and is leading China in high technology and high value-added manufacturing activity. By comparison, the three non-coastal regions are endowed with an abundant supply of semi-skilled labour, but inadequate capital, infrastructure and technology. 


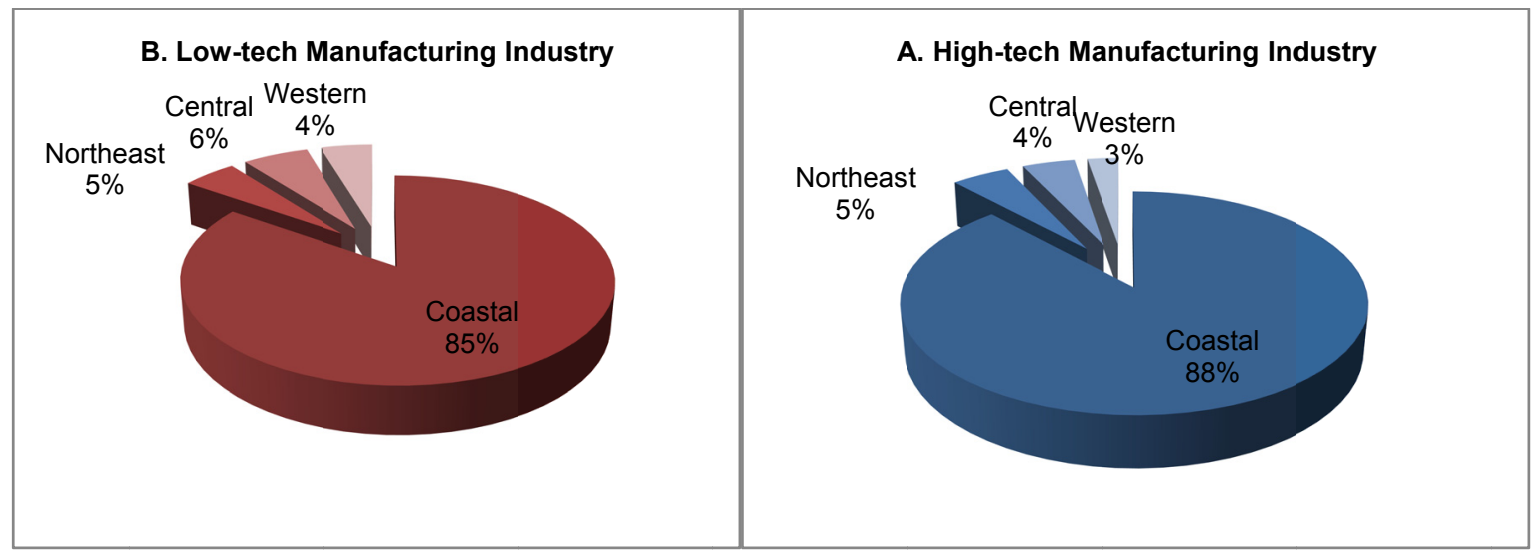

Figure 2. Regional Distribution of utilised FDI in high and low-tech manufacturing industry, 2001-2008 (\%)

Source: China Industrial Statistical Yearbook, 2002-2009

\section{Studies of Location Determinants of FDI in China}

There is a growing amount of literature on the determinants of foreign capital inflow into China, including those of Dee (1998), Sun et al (2002), Hou (2002), Cheng and Kwan (2000), Chen and Wu (2005) and Gao (2005). However, little research has been done on identifying the regional determinants of FDI on an industry basis especially those that differentiates the degree of technological intensity. Such a study is necessary to inform policy on FDI location given that FDI inflow into China is transforming from traditional labour-intensive, low-technology manufacturing sector to high-tech, and capital-intensive manufacturing sectors in recent years.

Previous researchers have identified determinants of foreign investment, and most assume that foreign investors will choose to invest in a particular location based on per capita income, agglomeration, labour quality, labour cost, transportation network and expenditures to attract foreign investment. Wang and Swain (1997) find that the FDI in manufacturing sectors is positively related to China's GDP, GDP growth rate, wages and trade barriers, but negatively related to interest rate and exchange rate for the period of 1978-1992. Cheng and Kwan (2000) report that good infrastructure positively influences the location decision of foreign investors in China. Similarly, Sun et al (2002), similarly report that good infrastructure has a positive effect on FDI inflow to China for the period 1986-1998. However, Mudambi \& Mudambi (2005) show that good infrastructure supports do not always attract significant FDI, especially into the high-technology sector. Zhang and Yuk (1998) examine the determinants of FDI in manufacturing industry coming from Hong Kong's investors into Guangdong province of China and also compare the difference between capital-intensive and labour-intensive FDI. They find that labour-intensive industries attract more export-oriented FDI, while capital-intensive industries attract FDI that are more domestic market-oriented. They also found the most important determinants are cheap labour and land, stable political environment, government incentive policies, good infrastructure, absence of language barrier and the geographical proximity of Guangdong province to Hong Kong. When NG and Tuan (2006) identify the determinants of FDI in manufacturing in Guangdong province by using firm-level data, they find that institutional force and agglomeration are both have positively related to the level of FDI inflows.

Based on comparative advantage, Qiu (2003) constructs a FDI model and finds that host country's comparative advantage sectors will be more attractive to FDI than its comparative disadvantage sectors. He then explains as to why prominent FDI invest in China's labour-intensive sector, arguing that this is the case as China has comparative advantage due to its large supply of labour and relative low cost of input materials. Milner and Pentecost (2006) come to the same conclusions when they test the determinants of US foreign direct investment in the UK's manufacturing sector, they find the comparative advantage in UK in terms of unskilled labour is an important factor attracting U.S. FDI. Furthermore, Dunning (2009) also argue that as foreign affiliates became more embedded in the host countries leading firms to engage in innovation activities. Lin and Kwan (2011) extend this argument and test the determinants of FDI across 29 manufacturing industries in China over 2000-2007, they find that FDI location is also influenced by high productivity, less State Owned Enterprises (SOE) presence, which in turn allows them to sustain monopolistic power in the market, MNEs may rely on $R \& D$ activities, thus the degree of FDI penetration is higher in R\&D intensive industry. 


\section{Determining Factors of FDI in Manufacturing Industry across Low and High-tech Manufacturing Industries}

This paper adopts the theoretical framework developed by Dunning (1988), knows as the Duning's OLI paradigm or eclectic paradigm, which focuses on ownership advantage, location advantage and internalisation advantage. According to this paradigm, in order to offset the disadvantages of setting up foreign production, the multinationals (MNCs) must have an ownership advantage; this may take the form of innovatory capacity, trademarks, reputation, or other tangible assets. Further, a location advantage in the host country may arise from superior factor quality, transport development, endowments, government policies and internalisation advantage where the firm is better off producing internally rather than outsourcing. In this paper, the ownership and internalisation advantages are taken as given. Using the OLI paradigm, the level of inward FDI flowing into a particular destination can partly be explained in terms of different location characteristics.

Based on OLI paradigm and empirical studies previously discussed, eight potentially important determinants of FDI inflows across four regions in China are identified in this study. As summarised in Table 3, these are market size (i), absorptive capacity (ii), supply of unskilled labour (iii), labour cost (iv), physical infrastructure (v), telecommunication (vi), government incentives (vii) and agglomeration (viii).

Market size, has a positive impact on regional attraction of foreign capital on both high and low-tech manufacturing industries, as it directly affects the expected revenue from domestic market. In fact, one of the motivations of setting up foreign affiliates in the host country is to supply goods and services to the domestic market. This kind of investment is undertaken to exploit new markets, thus, the market size, market growth rate, and degree of development of host country are very important for FDI. This implies that the larger the host market, the faster the rate of economic growth, the area will attract more FDI. Also, in this paper, GDP per capita is used to represent market size. (GDPPC in USD dollar)

Absorptive ability refers to the effectiveness of technology transfer from home country to host location (Lin et al, 2011). Previous research shows that the host country must have a moderate technological gap with MNEs in order to attract MNEs to establish foreign subsidiaries and to transfer advanced technology. If the technological gap is too wide, the host may not have the ability to adopt the technology associated with MNEs and thus will not experience an increase in total productivity (Kinoshita, 2001). Research also reveals that higher expenditure on R\&D increases the regional capacity to absorb more advanced foreign technology, which in turn, attracts more high-tech manufacturing FDI. In this paper, the government spending on Research \&Development (R\&D) is used to indicate absorption capacity (RESEARCH in USD million).

Supply of unskilled labour is another crucial factor in attracting FDI, especially in low-tech manufacturing industry. Initially, FDI into China was based on comparative advantage in labour-intensive production across the coastal region due to the region's large amount of unskilled labour and lower cost of production. However, the differences in regional distribution of foreign direct investment have also contributed to the increased wage disparity across regions $(\mathrm{Yu}$, et al, 2011). Data indicates that the average wage level across the coastal region is higher than all three non-coastal regions. This feature alone partly explains why low-tech, labour-intensive manufacturing production is shifting from the coastal region to inland regions. The large amount of unskilled labour in those regions is an essential factor for low-tech manufacturing FDI, thus, it is hypothesised that unskilled labour (UNSKILL, \%) has a positive relationship with low-tech FDI.

Labour cost calculated as the average wage paid in the manufacturing industry (WAGE in USD Dollar) is expected to have a positive and a negative effect on FDI. Here it is argued that the higher the wage, the lower the revenue, which in turn reduces the attractiveness for FDI. On the other hand, in recent years, China attracts foreign investment in more technology-intensive industries and MNCs are paying a premium to attract better quality workers. Labour cost may therefore reflect labour quality, thus the sign of wage variable can be both positive and negative (WAGE, USD dollar) 
Table 3. Determinants of FDI Inflow

\begin{tabular}{|c|c|c|}
\hline Independent Variable & Proxy Variable (Variable Name) & Expected Sign \\
\hline Market Size & Real GDP per capita (GDPPC) & + \\
\hline Absorptive capacity & Government spending on research and development (RESEARCH) & $\begin{array}{l}+ \text { (high-tech } \\
\text { manufacturing only) }\end{array}$ \\
\hline Labour cost & $\begin{array}{l}\text { Annual average wage paid by the manufacturing industry } \\
\text { (WAGE) }\end{array}$ & $+/-$ \\
\hline Supply of unskilled labour & $\begin{array}{l}\text { Percentage of total labour force with primary degree or below } \\
\text { (UNSKILL) }\end{array}$ & $\begin{array}{l}+ \text { (Low-tech } \\
\text { manufacturing only) }\end{array}$ \\
\hline Physical infrastructure & $\begin{array}{l}\text { Total length of highway and railway and inland waterway } \\
\text { (HRWLENGTH) }\end{array}$ & + \\
\hline Telecommunication & Length of cable (TELECOM) & + \\
\hline Government incentives & Total number of different types of zones(SZONES) & + \\
\hline Agglomeration & $\begin{array}{l}\text { Foreign capital in low-tech industry in the previous year (AGGLOL); } \\
\text { Foreign capital in high-tech industry in the previous year } \\
\text { (AGGLOH) }\end{array}$ & $+/-$ \\
\hline
\end{tabular}

Physical infrastructure and telecommunication development is another major determinant of FDI. Adequate and effective transportation can influence a firm's cost and revenue and hence their location decision. The level of infrastructure development of a particular region is found in many studies to be positively correlated to FDI. In this study, direct measure of physical infrastructure (HRWLENGTH, kilometers) is measured by the total length of highway, railway and inland waterway in a region. Graf and Mudambi (2005) argue that telecommunication infrastructure is especially important for IT-enabled business, and the availability of telecommunication infrastructure is significant condition for the attractive location for FDI, in this paper, the telecommunication infrastructure development is measured by total length of cable(TELECOM, kilometres.)

The government incentive to attract FDI is proxied by the number of special zones in each region. In these special zones, foreign investors can enjoy preferential policies, such as exemption from or reduction in the payment of profit taxes, land fees, import duties, as well as receive priority to obtain infrastructure services. In turn, the regions with more zones become more attractive to foreign investment. Thus, it is hypothesised that the number of zones in each region (SZONES, unit) has a positive relationship with FDI inflow for both high and low-tech manufacturing industries

Agglomeration refers to the concentration of economic activities that can lead to a further lead to economies of scale and positive externalities (Sun et al, 2002). The level of agglomeration of a particular region is positively related to higher FDI inflows. Similarly, the presence of low-tech FDI inflows may provide a signal for further FDI flows from other MNCs. On the other hand, high concentration of one type of industry may cause competition and therefore reduce the attractiveness of a location. Given these arguments, the agglomeration effect on FDI can be both positive and negative. In this paper, the foreign capital received in previous year in low and high-tech manufacturing industries is used to measure the agglomeration effects on both high and low-tech FDI, respectively.( AGGLOL and AGGLOH, USD million).

\section{Data and Analytical Framework}

This paper employs a panel data set of manufacturing industries reported by the China Industrial Economic Statistical Yearbook. It is the only official source that has a detailed and consistent data entries under separate categories for different industries in different provinces. It should be noted that there is a mismatch between the sectoral classifications for China's industrial statistical report (GB/T 4754) and the ISIV.3. By carefully comparing the definitions of these two systems and combining some industries under GB/T 4754 classification we were able to construct a balanced panel data set, which contains sixteen (16) manufacturing sectors. Seven (7)of these manufacturing industries are in low-tech category and nine (9) are in low-tech category. As the 'China Industrial Statistical Yearbook-2005 (report 2004's data)' is not available, the foreign investment in different industries was calculated by the average of 2003 data and 2005 data.

The empirical strategy was to establish two models for testing the determinants of FDI in both high-tech and low-tech manufacturing industries for the four regions. Employing the same model to identify the determinants of both high and low-tech manufacturing may give misleading results as the determinants of FDI across low-high tech firms may be different for different locations. For instance, FDI in high technology manufacturing 
industry may be attracted by higher absorption capacity in the coastal region while the low-tech manufacturing industry may be attracted by unskilled labour supply in inland regions, thus, specifying the type of manufacturing is essential.

All determinants, except the number of special zones are lagged by one (1) period. This was necessary for two reasons. Firstly, decisions to undertake FDI in a current year will not be realised as actual FDI flows do not eventuate until a year later, in other words, multinational FDI activities in a given year are based on information from the previous year. Secondly, the amount of FDI inflows and the independent variables may affect each other. In order to avoid the existence of an endogeneity problem arising; the GDPPC, WAGE, HRWLENGTH, TELECOM, RESEARCH and UNSKILL are transformed into natural logarithm.

Given the above arguments, the low-tech manufacturing industry locational model is specified as:

$$
\begin{gathered}
\text { FDIH }_{i t}=\alpha+\beta_{1} \text { GDPPC }_{i, t-1}+\beta_{2} \text { WAGE }_{i, t-1}+\beta_{3} \text { UNSKILL }_{i, t-1}+\beta_{4} \text { HRWLENGTH }_{i, t-1}+\beta_{5} \text { TELECOM }_{i, t-1} \\
+\beta_{6} \text { SZONES }_{i, t}+\beta_{7} \text { AGGLOH }_{i, t-1}+\varepsilon_{i t}
\end{gathered}
$$

Similarly, the high-tech manufacturing industry locational model is expressed as follows:

$$
\begin{gathered}
\text { FDIH }_{i t}=\alpha+\beta_{1} \text { GDPPC }_{i, t-1}+\beta_{2} \text { WAGE }_{i, t-1}+\beta_{3} \text { RESEARCH }_{i, t-1}+\beta_{4} \text { HRWLENGTH }_{i, t-1} \\
+\beta_{5} \text { TELECOM }_{i, t-1}+\beta_{6} \text { SZONES }_{i, t}+\beta_{7} \text { AGGLOH }_{i, t-1}+\varepsilon_{i t}
\end{gathered}
$$

Where subscript $i$ refers to individual provinces, $t$ refers to years from 2002 to 2010 . The variables are defined in Table 3.

\section{Empirical Results}

The descriptive statistics for all variables across the four regions are presented in Tables $4 \mathrm{a}$ to $4 \mathrm{~d}$. There are ten (10) provinces in the coastal region, three (3) provinces in northeast region and six (6) and eleven (11) provinces in central and western regions, respectively. Based on the mean value of FDI in each region, the coastal region recorded the highest average inflow in both high-tech and low-tech manufacturing industries (USD 12163 million and USD 6520 million), followed by the northeast region (USD 2159 million and USD 1391 million), western region (USD 1334 million and USD 810 million) and central region (USD 3328 million and USD 372 million). However, the coastal region also has the highest standard deviation in both categories. This indicates that the FDI inflows into the 10 provinces in the coastal region are more varied compared to other regions. The GDP per capita also exhibit a similar trend, with the coastal region has the highest GDP per capita, and followed by northeast region, central region and then the western region. Further, the wage which is measured by average annual salary paid to employee in manufacturing industry indicate that the western region has a higher annual wage compare to central region. This situation can be explained by the subsidies given to workers for working in the plateau area in the western region. Unskilled labour which is the percentage of total employees with primary degree or lower, the central and western region prove to have the worst compared to the coastal and northeast regions. For example, the percentage of 47.1 for the western region indicates that for 100 employees in manufacturing industry, only 47 persons have received the level of education of primary degree or below.

Government spending indicates the regions capacity for new and high technology. The coastal region's government invests significant amounts of money on R\&D (USD 2660 million) compared to northeast region (USD 1020 million), central region (845 million) and western region (USD 450 million). As to the physical infrastructure and telecommunications denoted by HRWLENGTH and TELECOM, respectively, the total length of highway, railway and inland waterway and cable in central and western regions are much longer than coastal region as they represent a much larger land area compare to coastal region. In terms of special zones the coastal region has the highest zones, the highest number of special zones in a province in the coastal region was 40 , in northeast, central and western region, and they were 16,11 and 11, respectively. 
Table 4a. Descriptive Statistics-Coastal region

\begin{tabular}{llrrrr}
\hline Variable & Observations & Mean & Std. Dev. & Min & Max \\
\hline FDIH & 90 & 12163.1 & 14831.1 & 32.9 & 70474.0 \\
FDIL & 90 & 6519.9 & 6646.9 & 207.4 & 28141.4 \\
GDPPC & 90 & 3827.8 & 2455.4 & 862.0 & 11563.3 \\
WAGE & 90 & 2552.6 & 1274.2 & 935.7 & 6832.4 \\
UNSKILL & 90 & 25.8 & 10.9 & 6.6 & 44.0 \\
RESEARCH & 90 & 2659.8 & 2823.4 & 9.7 & 12558.9 \\
HRWLENGTH & 90 & 74892.7 & 62952.9 & 8366.5 & 231391.0 \\
TELECOM & 90 & 14919.0 & 12952.2 & 333.0 & 45807.0 \\
SZONES & 90 & 12.8 & 8.2 & 3.0 & 40.0 \\
AGGLOH & 90 & 10111.3 & 12747.1 & 32.9 & 63104.2 \\
AGGLOL & 90 & 5567.3 & 5794.2 & 188.6 & 26105.8 \\
\hline
\end{tabular}

Table 4b. Descriptive Statistics-Northeast region

\begin{tabular}{lcrrrr}
\hline Variable & Observations & Mean & Std. Dev. & Min & Max \\
\hline FDIH & 27 & 2158.9 & 2464.3 & 156.6 & 9092.0 \\
FDIL & 27 & 1390.6 & 1196.8 & 224.2 & 4636.2 \\
GDPPC & 27 & 2245.1 & 1121.0 & 923.0 & 5158.7 \\
WAGE & 27 & 2103.4 & 969.4 & 997.3 & 4130.9 \\
UNSKILL & 27 & 25.9 & 3.1 & 20.7 & 30.6 \\
RESEARCH & 27 & 1020.3 & 898.3 & 199.3 & 4208.8 \\
HRWLENGTH & 27 & 85487.1 & 35985.8 & 45095.6 & 162357.0 \\
TELECOM & 27 & 23133.3 & 9158.6 & 10108.0 & 41304.0 \\
SZONES & 27 & 8.0 & 4.1 & 5.0 & 16.0 \\
AGGLOH & 27 & 1818.9 & 2071.0 & 156.6 & 7940.7 \\
AGGLOL & 27 & 1112.2 & 1032.7 & 209.0 & 4636.2 \\
\hline
\end{tabular}

Table 4c. Descriptive Statistics-Central region

\begin{tabular}{lrrrrr}
\hline Variable & Observations & Mean & Std. Dev. & Min & Max \\
\hline FDIH & 54 & 1033.6 & 965.0 & 80.8 & 3883.9 \\
FDIL & 54 & 810.2 & 609.6 & 130.2 & 2450.0 \\
GDPPC & 54 & 1542.3 & 788.1 & 630.8 & 3319.7 \\
WAGE & 54 & 1866.4 & 872.7 & 805.1 & 3686.6 \\
UNSKILL & 54 & 33.8 & 7.8 & 20.7 & 48.6 \\
RESEARCH & 54 & 845.0 & 783.1 & 94.2 & 3866.2 \\
HRWLENGTH & 54 & 123686.5 & 56171.8 & 60348.2 & 247530.0 \\
TELECOM & 54 & 23060.5 & 6287.7 & 11352.0 & 36431.0 \\
SZONES & 54 & 3.8 & 1.1 & 2.0 & $11 . .0$ \\
AGGLOH & 54 & 849.3 & 835.8 & 80.8 & 3883.9 \\
AGGLOL & 54 & 665.2 & 509.1 & 121.3 & 2338.9 \\
\hline
\end{tabular}


Table 4d. Descriptive Statistics-Western region

\begin{tabular}{lrrrrr}
\hline Variable & Observations & Mean & Std. Dev. & Min & Max \\
\hline FDIH & 99 & 327.8 & 439.0 & 1.8 & 2316.4 \\
FDIL & 99 & 371.9 & 421.2 & 8.8 & 1805.9 \\
GDPPC & 99 & 1482.2 & 964.3 & 349.8 & 5896.9 \\
WAGE & 99 & 2076.0 & 899.8 & 813.5 & 4065.3 \\
UNSKILL & 47.1 & 20.6 & 30.3 & 225.8 \\
RESEARCH & 99 & 449.5 & 648.2 & 14.5 & 3869.1 \\
HRWLENGTH & 99 & 94377.5 & 57878.6 & 12087.6 & 263146.0 \\
TELECOM & 99 & 23992.3 & 12471.2 & 3895.0 & 77292.0 \\
SZONES & 99 & 3.9 & 2.0 & 1.0 & 11.0 \\
AGGLOH & 99 & 274.2 & 362.9 & 1.8 & 1881.6 \\
AGGLOL & 99 & 294.5 & 336.4 & 8.2 & 1590.5 \\
\hline
\end{tabular}

The estimation results of the model are presented separately in two tables. Table 5.5a shows the determinants of foreign capital in low-technology manufacturing industries, while table $5.5 \mathrm{~b}$ shows these for the high-tech manufacturing industries. The high value of the overall $\mathrm{R}$-square in both models except for the northeast region indicates that the explanatory variables in the model explain most of the variation in the dependent variables, i.e., the equation are capturing the major determinants of FDI in both low and high-tech manufacturing FDI in the coastal region, central and western regions in China. Both models have a poor explanatory power for the northeast region, as the overall R-square values are only 0.2742 and 0.0016 for the low-technology and high-technology categories, respectively. This may be due to the relatively small number of observations for this region in this study.

\subsection{Empirical Results and Discussion of Location Determinants for Low-tech Manufacturing FDI across the Four Regions}

The regression results of location determinants of low-tech manufacturing FDI shows a mixed picture amongst the four regions in China (Table 5a). For the coastal region, market size (GDPPC) has a significant positive effect on low-tech FDI (Table 5a, Column 1) i.e., rapid growing domestic market attracts low-tech FDI to the coastal region. This result indicates that low-tech FDI in the coastal region is not only export-oriented but also domestic market-oriented given that the coastal region has the highest population density and highest household income compared to other regions. The labour cost (WAGE) and supply of unskilled labour (UNSKILL) both have a negative effect on low-tech FDI inflows, however, only the WAGE variable has scientific significant effect. Generally speaking, low-tech FDI is motivated by cheap and unskilled labour in the host location, however, the overall labour quality in coastal region is much higher compared to the other three regions, thus, even for low-tech FDI, foreign investors need to pay more for the same task. In terms of employee educational attainment, by the end of 2009, 14 per cent of total employees in the coastal region has college degree or above, in Beijing and Shanghai municipalities, the proportion were 35.9 per cent and 31.3 per cent, respectively, while the proportion of total employee with college degree or higher were 12.2 per cent, 9.3 per cent and 6.3 per cent in the western region, the northeast region and central region, respectively. Physical infrastructure (HRWLENGTH) and telecommunication infrastructure (TELECOM) both have positive but insignificant effects on low-tech FDI in coastal region. This result implies that physical and telecommunication developments are important for foreign investors as most of products produced by FFEs are exported to FFEs' home countries or other destinations. For instance, in 2010, the total export from FFEs in coastal region was USD 808.3 billion, which equal 93.8 per cent of total export from FFEs. However, inland highways, railways and waterways and telecommunication development were not as important as seaports located in the coastal region. The government incentive to attract FDI was measured by the number of special zones (SZONES). Until 2010, there are 302 different zones established in China, which 165 were located in coastal region. Special zones offer preferential policies to foreign investors in terms of tax deduction, cheap land and energy fees, however, a high concentration of special zones located in the same region may actually reduce their attractiveness and also increase the competition between firms who located in the special zones, as they may face competitions in terms of labours, land uses and infrastructure. Thus, even though setting special zones has a positive effect on the attractiveness of the coastal region, the effect is not significant. The regression results show a highly significant positive agglomeration effect (AGGLO) on low-tech FDI in the coastal region, agglomeration not only measures the positive economic externality it also indicates the risk involved for new investors. Large amount of FDI inflows 
located in the coastal region previously indicates the region is more market-oriented with a foreign business environment.

Table 5a. Determinants of foreign capital in low-tech manufacturing industry among four regions

\begin{tabular}{|c|c|c|c|c|}
\hline & $\begin{array}{r}\text { Coastal } \\
(1) \\
\end{array}$ & $\begin{array}{c}\text { Northeast } \\
(2)\end{array}$ & $\begin{array}{r}\text { Central } \\
(3) \\
\end{array}$ & $\begin{array}{r}\text { Western } \\
(4) \\
\end{array}$ \\
\hline \multirow{2}{*}{ CONS } & -0.1060 & -6.5670 & -1.3539 & -5.8572 \\
\hline & $(0.910)$ & $(0.027)^{* *}$ & $(0.584)$ & $(0.034)^{* *}$ \\
\hline \multirow{2}{*}{ GDPPC } & 0.7600 & -0.0031 & 0.1546 & 1.5108 \\
\hline & $(0.006)^{* * *}$ & $(0.995)$ & $(0.755)$ & $(0.052)^{*}$ \\
\hline \multirow{2}{*}{ WAGE } & -0.4791 & 0.3616 & 0.2599 & -0.9733 \\
\hline & $(0.075)^{*}$ & $(0.632)$ & $(0.602)$ & $(0.330)$ \\
\hline \multirow{2}{*}{ UNSKILL } & -0.0113 & -0.0037 & -0.0052 & 0.0001 \\
\hline & $(0.152)$ & $(0.813)$ & $(0.603)$ & $(0.982)$ \\
\hline \multirow{2}{*}{ HRWLENGTH } & 0.1689 & 0.3276 & 0.0838 & 0.4393 \\
\hline & $(0.124)$ & $(0.165)$ & $(0.614)$ & $(0.091)^{*}$ \\
\hline \multirow{2}{*}{ TELECOM } & 0.0579 & 0.3783 & -0.0160 & 0.2841 \\
\hline & $(0.213)$ & $(0.290)$ & $(0.954)$ & $(0.246)$ \\
\hline \multirow{2}{*}{ SZONES } & 0.0014 & -0.1320 & -0.0424 & -0.0130 \\
\hline & $(0.880)$ & $(0.007)^{* *}$ & $(0.119)$ & $(0.858)$ \\
\hline \multirow{2}{*}{ AGGLOL } & 0.4777 & 0.6668 & 0.6844 & 0.0006 \\
\hline & $(0.000)^{* * *}$ & $(0.001)^{* * * *}$ & $(0.000)^{* * * *}$ & $(0.996)$ \\
\hline R-sq(overall) & 0.9133 & 0.2742 & 0.8825 & 0.4439 \\
\hline Prob > chi2 & 0.0000 & 0.0000 & 0.0000 & 0.0000 \\
\hline
\end{tabular}

Note: 0 represents p-value, ***,**, * denote statistical significance at $1 \% .5 \%$ and $10 \%$ level, respectively

The empirical results of the regional determinants of low-tech manufacturing FDI in the northeast and central regions are represented in Table 5a, column 2 and 3. The wage variables (WAGE) has a positive sign in both regions, while the supply of unskilled labours (UNSKILL) has a negative sign in both regions. Combining these two variables, indicates that even for low-tech manufacturing activities, there was a mismatch between the basic skills of labour force and FFEs requirements, which indicates that FFEs are willing to pay a higher wage to get better skilled labour. Meanwhile, the inland physical infrastructure development appears insignificant in attracting low-tech manufacturing FDI inflow in both regions, these results indicate low-tech FDI inflows in these two regions are more domestic market-oriented than export-oriented, as a result, inland infrastructure development is not an important location factor for low-tech FDI. The government incentive to attract low-tech FDI by setting up special zones (SZONES) also failed in these two regions. For northeast region, there were ten (10) different types of special zones were set up in the period of 2000-2010, within the ten (10) special zones, 4 are export-processing zones, one (1) was high-tech development zone and five (5) were national economic and technological development zones. In the same period, the central region established 32 special zones, with 23 zones established as economic and high-tech development zones. Based on the nature of special zones, the regional governments are trying to attract more high-tech FDI instead of low-tech FDI. However, this will not match with the regional characteristics, such as labour quality. Thus, establishing special zones reduce the attractiveness of low-tech FDI in northeast region. The agglomeration effects (AGGLOL) have statistical significant positive effect on low-tech FDI in both two regions; with both significant at 1 per cent level.

In the western region, market size measured by GDPPC and physical infrastructure measured by HRWLENGTH are the only two variables that have a significant effect on low-tech FDI. Geographically the western region comprises of mountains, plateaus and basins, with a difficult environment to construct basic infrastructure such as roads and utilities supply which in turn makes the region too costly to export products overseas. As a result, domestic market and intraregional infrastructure development are two important variables for low-tech FDI. Although western regions labour supply predominantly live in rural areas, they do not have the basic skills for manufacturing production, the supply of unskilled labour (UNSKILL) has a positive but not significant effect on low-tech FDI. The effect of establishing special zones to attract low-tech FDI was also not significant. Since China adopting 'western development' strategy since 1999, there were 35 different types of special zones were established, 24 were economic and technology development zones, three (3) high-tech zones, eight (8) were 
export-processing zones. However, due to the economic development, labour quality and physical infrastructure development, setting up zones was not sufficient enough to attract foreign investors. In addition, three (3) high-technology zones and eight (8) export-processing zones were not suitable for western region. Firstly, the research and research development facilities and human resources were not superior, secondly, the major importers of China's products are U.S. and European Union, for them, the transportation cost is high due to the distance and infrastructure development. Thus setting up export-processing zones does not increase attractiveness of the western region.

\subsection{Empirical Results and Discussion of Location Determinants of High-tech Manufacturing FDI across Four Regions}

The regional determinants of high-tech FDI inflows across the regions provide a mixed picture (Table 5b). Due to the large amount of high-tech located in coastal region, the model fits the coastal region the most, with the overall R-square 0.9758 . In the period 2001-2008, the coastal region attracted 88 per cent of total high-tech FDI to China. The empirical results shows FFEs establish high-tech manufacturing production in the coastal region was attracted by better telecommunication development (TELECOM) and the economic externality (AGGLOH) as these two variables are both highly significant at 1 per cent level. Compared to other developed countries, the average wage in the coastal region is low, thus, the wage variable (WAGE) shows a negative but insignificant effect on high-tech FDI in the coastal region. The variable RESEARCH measures the government spending on R\&D; it shows an insignificant effect on high-tech FDI. This indicates that the training provided by coastal region was not valued by foreign investors, as they are willing to increase labour skills by on-job training.

In contrast, in the northeast region, government spending on research and development (RESEARCH) has a positive significant effect on high-tech FDI. A 1 per cent increased in government spending on R\&D would increase high-tech FDI by 0.82 per cent. Moreover, the physical infrastructure (HRWLENGTH) and telecommunication (TELECOM) development appear with expected signs in northeast region (Table 5b, column 2), i.e. the better the physical and telecommunication developments, the more FDI is attracted into northeast region. However, establishing special zones was not a significant aspect in attracting high-tech FDI over the period 2001-2008. Recall the same argument applied in the case of low-tech FDI, the effect of setting up special zones for low-tech FDI depends on the nature of zones and the number of zones in an area. If there are too many zones in an area, they are limiting the advantage business coming from outside the zones due to competitions.

In the central region, the domestic market size (GDPPC) has no significant effects on high-tech FDI (Table 5b, column 3). This can be explained by the fact that major investors in the northeast region are from Japan and South Korea, whose final products are exported back to their home countries instead of serving domestic market. Thus, the size of domestic market has no effect on high-tech FDI. The labour cost (WAGE) has the expected sign but is insignificant, recall that the overall labour cost in China while low the wage level has limited implication for foreign investors. Both telecommunications (TELECOM) and physical infrastructure (HRWLENGTH) have positive signs, but are insignificant.

Comparing high-tech FDI to low-tech FDI, the former involves significant costs such as the large amount of initial investment on machinery, $\mathrm{R} \& \mathrm{D}$ and labour training; however experiences of existing firms play an important role for new investors. The agglomeration (AGGLOH) effect appears positive for high-tech FDI, which is also significant at the 1 per cent level. A 1 percent in increase of high-tech FDI will increase 0.91 per cent for the next year. Government incentive to attract high-tech FDI by setting up special zones (SZONES) has also failed in the northeast region; with the variable appearing to be insignificant with a negative sign. This implies the preferential policies implied in zones are not matched with foreign investors' decisions to set up in the region. 
Table $5 \mathrm{~b}$. Determinants of foreign capital in high-tech manufacturing industry among four regions

\begin{tabular}{|c|c|c|c|c|}
\hline & $\begin{array}{r}\text { Coastal } \\
(1) \\
\end{array}$ & $\begin{array}{c}\text { Northeast } \\
(2)\end{array}$ & $\begin{array}{r}\text { Central } \\
(3) \\
\end{array}$ & $\begin{array}{r}\text { Western } \\
(4) \\
\end{array}$ \\
\hline \multirow{2}{*}{ CONS } & -2.2356 & -10.1900 & -3.4573 & 0.4994 \\
\hline & $(0.034)$ & $(0.004) * *$ & $(0.271)$ & $(0.794)$ \\
\hline \multirow{2}{*}{ GDPPC } & 0.4004 & 0.6206 & -0.2520 & 0.5805 \\
\hline & $(0.167)$ & $(0.384)$ & $(0.705)$ & $(0.318)$ \\
\hline \multirow{2}{*}{ WAGE } & -0.1805 & -1.3179 & -0.3818 & -0.7477 \\
\hline & $(0.453)$ & $(0.264)$ & $(0.561)$ & $(0.291)$ \\
\hline \multirow{2}{*}{ RESEARCH } & 0.0035 & 0.8207 & 0.3976 & 0.1847 \\
\hline & $(0.975)$ & $(0.015)^{* *}$ & $(0.282)$ & $(0.344)$ \\
\hline \multirow{2}{*}{ HRWLENGTH } & 0.1194 & 0.7014 & 0.0041 & -0.0219 \\
\hline & $(0.181)$ & $(0.010) * * *$ & $(0.983)$ & $(0.910)$ \\
\hline \multirow{2}{*}{ TELECOM } & 0.1832 & 0.9367 & 0.6561 & 0.1860 \\
\hline & $(0.000) * * *$ & $(0.019) * *$ & $(0.060)^{*}$ & $(0.314)$ \\
\hline \multirow{2}{*}{ SZONES } & -0.0066 & -0.1298 & -0.0588 & -0.0142 \\
\hline & $(0.430)$ & $(0.023)^{* *}$ & $(0.180)$ & $(0.793)$ \\
\hline \multirow{2}{*}{ AGGLOH } & 0.7269 & 0.1212 & 0.9071 & 0.7045 \\
\hline & $(0.000) * * *$ & $(0.594)$ & $(0.000)^{* * * *}$ & $(0.000) * * *$ \\
\hline R-sq(overall) & 0.9758 & 0.0016 & 0.8877 & 0.9501 \\
\hline Prob $>$ chi2 & 0.0000 & 0.0000 & 0.0000 & 0.0000 \\
\hline
\end{tabular}

Note: () represents p-value, ***,**, * denote statistical significance at $1 \% .5 \%$ and $10 \%$ level, respectively

For the western region, none of the location determinant variables are statistically significant, except the agglomeration effect (Table 5b, 4). Results show that the western region has never been an attractive destination for foreign investment since China opened its door to trade and investment. This result is further supported by the fact that the western region only receives 3 per cent of high-tech FDI in China. Market size (GDPPC), labour quality (RESEARCH), physical infrastructure (HRWLENGTH) and telecommunication (TELECOM) all have insignificant effects on high-tech FDI in the western region. This implies although government has tried to establish special zones and implemented preferential policies to attract foreign investors, it cannot attract investors due to the nature of the underdeveloped economic environment and unskilled labour force this is further confirmed by the negative and insignificant signs appearing for SZONES variable.

\section{Conclusion}

The purpose of this paper was to investigate the local determinants of FDI. In order to provide accurate information for policy makers to attract the appropriate FDI technology into a location, we separated manufacturing industries into low and high tech categories according to their research intensity. Overall we find that foreign capital investment in China has migrated from low to high tech manufacturing industry. However, from a geographical perspective each region has distinct physical characteristics, where one region attracts high-tech while another region is attracted to low-tech manufacturing.

The empirical testing suggests that the important determinants of low-tech FDI in the coastal region are the domestic market, labour cost, and agglomeration effect, while the important determinants for high-tech are the development of telecommunication. To attract greater FDI into this area, policy makers should continue to invest in telecommunication development and open more domestic markets to foreign investors. For the three inland regions, physical infrastructure is essential to increase the attractiveness for both high-tech and low-tech FDI, while the telecommunication development is especially important for northeast and central regions.

Based on the empirical results, the policy implications are: regards the coastal region, the government should continue to invest in research and development in order to attract more high-tech FDI. In order to reduce regional disparities, the Chinese government should improve the regional investment environment, and implement more preferential policies, however, the preferential policies should be more location specific and industry based. For the inland regions, especially the western region, endowed with rich natural resources, the government should encourage resource-seeking, low-tech FDI, such as mining and raw material industries. In addition the coastal region should continue attracting export-oriented FDI with government promoting export-oriented FDI, and exporting to their neighboring countries, e.g. Russia and India. Infrastructure development is essential to 
encourage FDI into the western region. This region should invest more in physical infrastructure, to increase the attractiveness of low-tech FDI.

\section{References}

Billington, M. (1999). The location of foreign direct investment: an empirical analysis. Applied Economics, 31, 65-76. http://dx.doi.org/10.1080/000368499324561

Chen, C. (2011). Foreign direct investment in China: location determinants, investor differences and economic impacts. Northampton, MA: Edward Elgat.

Chen, Z., Ge, Y., \& Lai, H. (2011). Foreign Direct Investment and Wage Inequality: Evidence from China. 39. World Development, 39(8), 1322-1332. http://dx.doi.org/10.1016/j.worlddev.2010.12.006

Cheng, L., \& Kwan, Y. K. (2000). The location of foreign direct investment in Chinese regions: Further analysis of labour quality. In: Krueger, A. O. (ed.), The Role of Foreign Direct Investment in East Asian Economic Development. University of Chicago Press.

Chen, C. H., \& Wu, H. L. (2005). Determinants of regional growth disparity in China's transitional economy. Journal of Economic Studies, 32(5), 406-419. http://dx.doi.org/10.1108/01443580510622397

DEES, S. (1998). Foreign Direct Investment in China: Determinants and Effects. Economics of Planning, 31, 175-194. http://dx.doi.org/10.1023/A:1003576930461

Dunning, J. H. (1988). Explaining International Production. Boston, MA:Unwin Hyman.

Dunning, J. H. (2009). Location and the Multinational Enterprise: John Dunning's Thoughts on Receiving the "Journal of International Business Studies" 2008 Decade Award. Journal of International Business Studies, 40, 20-34. http://dx.doi.org/10.1057/jibs.2008.75

GAO, T. (2005). Labor quality and the location of foreign direct investment: Evidence from China. China Economic Review, 16, 274-292. http://dx.doi.org/10.1016/j.chieco.2005.02.005

Graf, M., \& Mudambi, S. M (2005). The outsourcing of IT-enabled business process: A conceptual model of the location decision. Journal of International management, 11, 253-268. http://dx.doi.org/10.1016/j.intman.2005.03.010

Hou, J. W. (2002). China's FDI policy and taiwanese direct investment (TDI) in China. Department of Economics, WCalifornia State University.

Kinoshita, Y. (2001). R\&D and technology spillovers through FDI: Innovation and absorptive capacity. C.E.P.R. discussion paper no. 2775. London: Centre for Economic Policy Research.

Lin, C. H., Lee, C. M., \& Yang, C. H. (2011). Does foreign direct investment really enhance China's regional productivity? The journal of international trade \& Economic Development: An international and comparative review, 20, 741-768.

LIN, M., \& KWAN, Y. K. (2011). Sectoral Location of FDI in China. The World Economy, 34, 1181-1198. http://dx.doi.org/10.1111/j.1467-9701.2011.01372.x

LIU, Z. (2008). Foreign direct investment and technology spillover: Theory and evidence. Journal of Development Economics, 85, 176-193. http://dx.doi.org/10.1016/j.jdeveco.2006.07.001

MILNER, C., \& PENTECOST, E. (2006). Locational advantage and US foreign direct investment in UK manufacturing. Applied Economics, 28, 605-615. http://dx.doi.org/10.1080/00036849600000040

Mudambi, R., \& Mudambi, S. M (2005). Multinational enterprises knowledge flows: the effec of government inward investment policy. Management International review, 45, 155-178.

NG, L. F., \& TUAN, C. (2006). Spatial agglomeration, FDI and regional growth in China: Locality of local and foreign manufacturing investment. Journal of Asian Economics, 17, 691-713. http://dx.doi.org/10.1016/j.asieco.2006.06.008

OECD Science. (2009). Technology and Industry Scoreboard, OECD.

Qiu, L. D. (2003). Comparing sectoral FDI incentives: Comparative advantages and market opportunities. Annals of economics and finance, 4, 383-408.

SHAUKAT, A., \& GUO, W. (2005). Determinants of FDI in China. Journal of global business and technology, $1,21-33$. 
SUN, H., \& CHAI, J. (1998). Direct foreign investment and inter-regional economic disparity in China. International Journal of Social Economics, 25, 424-447. http://dx.doi.org/10.1108/03068299810193687

SUN, Q., TONG, W., \& YU, Q. (2002). Determinants of foreign direct investment across China. Journal of International Money and Finance, 21, 79-113. http://dx.doi.org/10.1016/S0261-5606(01)00032-8

WANG, Z. Q., \& SWAIN, N. (1997). Determinants of Inflow of Foreign Direct Investment in Hungary and China: Time-Series Approach. Journal of International Development, 9, 695-726. http://dx.doi.org/10.1002/(SICI)1099-1328(199707)9:5<695::AID-JID294>3.0.CO;2-N

WEI, Y., \& LIU, X. (2006). Productivity spillovers from R\&D, exports and FDI in China's manufacturing sector. Journal of International Business Studies, 37, 544-557. http://dx.doi.org/10.1057/palgrave.jibs.8400209

WEI, K., YAO, S., \& LIU, A. (2009). Foreign direct investment and regional inequality in China. Review of development economics, 13, 778-791. http://dx.doi.org/10.1111/j.1467-9361.2009.00516.x

WHALLEY, J., \& XIN, X. (2010). China's FDI and non-FDI economies and the sustainability of future high Chinese growth. China Economic Review, 21, 123-135. http://dx.doi.org/10.1016/j.chieco.2009.11.004

Yang, D. (2010). Foreign direct investment and development of high-growth industrial sectors in China, 1998-2006. The Chinese Economy, 43, 93-114. http://dx.doi.org/10.2753/CES1097-1475430405

YAO, S. (2006). On economic growth, FDI and exports in China. Applied Economics, 38, 339-351. http://dx.doi.org/10.1080/00036840500368730

YU, K., XIN, X., GUO, P., \& LIU, X. (2011). Foreign direct investment and China's regional income inequality. Economic Modeling, 28, 1348-1353. http://dx.doi.org/10.1016/j.econmod.2011.02.026

Zhang, X., \& Yuk, H. P. (1998) Determinants of Hong Kong manufacturing investment in China: a survey. Marketing intelligence and planning, 16, 260-267. http://dx.doi.org/10.1108/02634509810224446

\section{Notes}

Note 1. All industries are classified based on International Standard Industrial Classification of All Economic Activities (ISIC) Rev.3. For more detailed explanation are provided by OECD Directorate for Science, Technology and Industry Economic Analysis and Statistics Division 